ISSN: $1305-578 \mathrm{X}$

Journal of Language and Linguistic Studies, 17(4), 1837-1852; 2021

\title{
Social contexts of the pronoun usage in Balinese
}

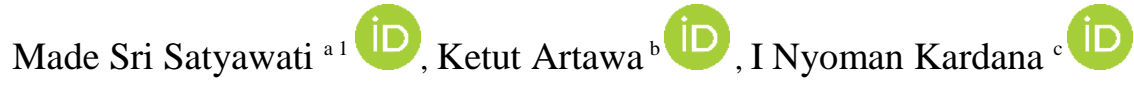 \\ ${ }^{a, b}$ Udayana University, Bali, Indonesia \\ ${ }^{c}$ Warmadewa University, Bali, Indonesia
}

\section{APA Citation:}

Satyawati, M.S., Artawa, K., \& Kardana, I.N. (2021). Social contexts of the pronoun usage in Balinese. Journal of Language and Linguistic Studies, 17 (4), 1837-1852. Doi: 10.52462/jlls.133

Submission Date:29/05/2021

Acceptance Date:03/08/2021

\begin{abstract}
There are a number of previous studies on the grammatical aspects of Balinese have been done, however, specific studies that deal with the social aspects of the language are still lacking. This research fulfils this gap and can be utilized in developing materials for teaching and learning Balinese. In this way, the interaction of linguistic research and language teaching and learning can be put into practice. Context in language use is very important. An utterance in one language has functions other than referential; the stylistic shifts of the utterance often mark different social relationships. Balinese is a language that employs speech styles or levels. The principal purpose of this research is to study the impact of the traditional social class which is known as the caste system on pronoun usage in Balinese. This study is a descriptive-qualitative study. It was conducted by observing the uses of pronouns found in Balinese written texts and the analysis and discussion are done descriptively. The results of the data analysis showed that the traditional caste system is significant in determining the choice of pronouns in Balinese.
\end{abstract}

Keywords: Pronoun; speech Style; Social Context; Caste system

\section{Introduction}

Balinese is a language spoken by 3.3 million mostly on the island of Bali, in the Indonesian archipelago. This also covers 7,000 Southern Sulawesi and western Nusa Tenggara refugees, as well as the West Lombok Island (Simons and Charles, 2018; Bratayadnya et al., 2021; Kusumarini et al., 2021). Balinese people in Indonesia are still speaking, including in Lampung, Java and so on. Geographic Balinese, or West Malay Polynesian, belongs to Austronesian language classes (Adelaar, 2005). Balinese is one the eastern-most members of the Western Malayo-Polynesian language family.

In Indonesian context (MİİCI, I., \& Şeyda, S. A. R. I. 2021) Balinese is a local language as opposed to Indonesian as the national language, Balinese is an identity for Balinese ethnic group (Gunasari et al., 2020). Balinese is a marker of the identity of Balinese people, the other social aspects which identify Balinese people is a caste system. This caste system in Balinese uses specific titles which are attached to their personal names according to which caste they are affiliated.

\footnotetext{
${ }^{1}$ Coresponding Author

E-mail address: srisatyawati@unud.ac.id
} 
Balinese has speech levels or styles. These speech styles are shown in all word classes. Thus, classes of word like noun, verb, adjective, preposition, pronoun, direction word and function words can be distinguished based on the speech styles. The word category in Balinese becomes an interesting topic for further research. Purnawati and Artawa (2018) studied Balinese temporal adverbials in Balinese. These temporal adverbials are maked by prepositions. The results show that Balinese temporal expressions can be classified into four main semantic functions. The choice of prepositions for marking temporal adverbials in Balinese is influenced by the speech styles.

Ekasriadi and Artawa (2019) investigated directionals in the Balinese language. Directionals in Balinese can be marked by the uses of adjectives, verbs and prepositions. The study showed that semantically in Balinese the use of directional is based on five variables; they are the mount-sea pivot, points of compass, the agent's goal, and the agent's physical position. The study revealed that the choice of the adjectives, verbs and prepositions used in sentence structures to mark directionals is determined by the speech styles.

The adverbial verbs in Balinese also showed that the distinction between a low and a high styles of the lexical verbs functioning as an adverbial (Purnawati and Artawa, 2020). Artawa, et.al (2020) described the adverbial clause marking strategies in Balinese. This showed that the adverbial clauses can be divided into eleven semantics roles in Balinese. At least, two separate markers for the same semantic function are given for both of those semantics functions, with at least two distinct markers in each semantician function; a low marker and a high marker.

Foley (1997:319) states that this grammatical morphemes and unique word groups suggesting social deixis among the interlocutor or a referent of the utterance speaker, various Asian languages have an elaborate scheme of honours. Foley (1997) also remarks that such terms are not known until the interlocutors are aware of the meaning of the utterance, of the position of participants, of the speaker's intention, of the location and time of the utterance. Holmes (1992:1) also states that "examining the way people use language in different social contexts provides a wealth of information about the way language works, as well as about the social relationships in a community".

Context plays an important part in language use. Linguistic and social practices must also be adapted to people and their social class and adapted to special circumstances and occasions. In other terms, language differs not only by the social features of the speaker, but also by the social context of which he participates. The application of language types should be properly applied according to the social standing and characteristics of the addressing individual in a society in which there is social stratification, as can be seen in Balinese societies. In a conversation in which the addresser is an individual with a greater social standing and the addresser has a lower social status, for instance, the language of the addresser reflects the social status of the two communication participants. In terms of grammatical aspects, all pronouns in Balinese show that they behave syntactically in the same way. However, their usage in relation to social context behaves differently. Therefore, the aim of the present study is to describe and discuss the role of social attributes or the caste system and social context attached to the speaker and addressee in determining the choice of pronouns and their usage in Balinese.

\section{Literature Review}

In several of the world's languages personal pronouns communicate deixi expressing different kinds of collectively defined knowledge about speakers. Alwi (2019:249) indicates, whether it reflects the addresser (first person pronoun, second person pronoun), or person as the subject of discussion, that a pronoun may be described as a word for reference to someone (third person pronoun). Pronouns even more than other areas of the language represent social relationships between individuals. 
Kersten (1984:28)) described the features of the first person pronoun of a high style in Balinese. The pronouns are titiang, tiang and icang. The form titiang is used in a high style to show respect to the addressee. The form tiang is used when speaking to a stranger or to the unknown person, whereas icang is used in a low style in every day communication among farmer families in the villages. Sulaga, et.al (1996:137) in their book, the standard grammar of Balinese language, classified pronouns in Balinese into first person pronouns (titiang, icing, raga), second person pronouns ( ragane, cai, nyai) and third person pronouns (ida, ipun, dane, ia). The examples provided in the book seem to be based on intuitive data from the authors. The classification of the pronouns is used as the basis for observing how they are used in Balinese written texts.

There are different, but related, ways of approaching the use of pronouns across-linguistically. Murphy (1988) examines the contextual element in the way speakers in a certain case select a reference in English. The results of the tests revealed that the speakers are responsive to the degree of intimacy and the corresponding individual, and to the recipient. However, the relation between the speaker and addressee has the least degree of influence for the choice of referring expression. The important contribution of this research is the choice of referring expressions or terms of address are socially driven phenomena. Martiny (1996) demonstrated that a socio pragmatic approach could provide fascinating new insights into the general behaviour of the addresses and the use of modes of speech, especially in the spoken French and Dutch.

It has become a trend of research on the so-called epicene pronominal usage in written English. The research reveals that he no longer prevails in the conventional way, though singular, they is the most commonly used pronoun (Barnowski, 2002). An additional research examining the usage of the epicene pronouns he, she, or they. Stomborn (2002) carried out the research in L1 and L2 companies of student writing. The analysis also indicates that both L1 and L2 authors in their pronoun choices are influenced by the precedent form.

Heine and Song (2011) note that some cultures are distinguished in personal relation and address. In Southeast and East Asia, these differences could be found. The diverse systems of personal pronounding, dependent on honorifical distinctions, are used in languages such as Thai, Burmese, Khmer, Vietnamese, Korean and Japanese. Uddin (2018) concluded that Bengali language has a very detailed and complex pattern of pronoun encoding systems which, as extension, functions as markers of social knowledge, in his study on the comparison of use in Bengali of the second person pronoun with pronouns of English of the second person. In contrast, in English, such functions are lacking a minimal deictic choice. You is not known to play the social and honorary functions of the English language as You in Bengali. Moreover, the second-person pronoun used in French-language online personal advertising from Quebec was analyzed by Compernolle (2008). Two key methods have been found for the study: Speaking with you, singular and plural address. Though a general preference has been noted for singular address you, young men frequently preferred to use plural you.

Levinson (1983:54) argues that the only way to represent the connections between language and meaning is through the phenomenon of deixis in the structure of the languages themselves. Among the deixis groups, an individual with a social dimension is specifically linked to this analysis. Address terms are often language types, and are used to approach people or to respond to them during conversations. It is often held that in a language's syntax, the best position for finding a correspondence is in pronouns and types of address.

We use various forms in different societal settings, because the interaction between language and contexts in which it is used is associated with sociolinguistics. As Holmes (1992:247) points out, "many considerations will help determine whether people live together or are part of the same family and so on to separate their social life or intimacy from those of related age, sex and social roles." The 
degree of formality is similarly useful to measure the impact of social circumstances. For example, types of addresses used with friends and family members might differ depending on the social formality, i.e., partners may apply personal forms to speak privately to one another while in a formal context transforming them into polite forms. Brown and Yule (1989:54) maintain that "different address words are used in different social settings." In short, all these previous studies are useful and will contribute to the understandings of the pronoun usage in Balinese.

\section{Method}

This is a descriptive-qualitative study that use of written text as data source. The sources of the written data are novels and short stories. While the intuitive data was conducted through elicitation. This is a qualitative study with descriptive data presentation. It is aimed at investigating the social context of pronoun usage in Balinese. In this study, the Balinese pronouns found the written documents. The data in this study was collected using observation Technique that is called a qualitative approach component. Observation is the way to gather data by significant language observation (Sudaryanto, 1993:136; Lu et al., 2021). The discovery was first made to specifically identify the form of personal pronouns used in the written Balinese language. The relevant data was cited and then classified according to the types of the pronouns contained in the data. The data was analyzed using the descriptive method. The discussion of this study is also presented descriptively.

\section{Result and Discussion}

In its pronominal scheme, Balinese does not distinguish number. to have a plural form, the phrase ajak makejang (low style) or sareng sami (high style) 'with all' is used together with the pronoun form. For example in Balinese we can have an expression like, raga ajak makejang 'we'. The pronouns in Balinese are in table 1.

Table 1. The Pronouns in Balinese

\begin{tabular}{|l|l|l|}
\hline Category & Low & High \\
\hline First person pronoun & $\begin{array}{l}\text { icang } \\
\text { kai } \\
\text { raga }\end{array}$ & $\begin{array}{l}\text { titiang } \\
\text { tiang } \\
\text { yang }\end{array}$ \\
\hline Second person pronoun & $\begin{array}{l}\text { iba } \\
\text { cai } \\
\text { nyai }\end{array}$ & $\begin{array}{l}\text { i ratu } \\
\text { ragane } \\
\text { jerone }\end{array}$ \\
\hline Third person pronoun & ia & $\begin{array}{l}\text { ida } \\
\text { dane } \\
\text { ipun }\end{array}$ \\
\hline
\end{tabular}

To understand the pronoun usage in Balinese, one must understand the social structure and social values of Balinese society. Traditionally Balinese society is based on hierarchy of the caste system.

This caste system can be distinguished into: triwangsa caste and jaba or sudra caste. The opposition can be made into jaba and non jaba caste. The non jaba castes are triwangsa caste. The non jaba castes have three membership castes: wiesya, ksatrya, and brahmna caste. This social stratification is expressed in the use of language types in the Balinese society (Tinggen,1986:1). This social stratification is a fundamental reason in using different styles of Balinese. 


\subsection{First person Pronouns}

The first person pronouns are cang, kai, iraga, titiang, tiang, and yang. Each of these pronouns is described in this sub-section.

Data 1 (cang)

Belog, dandanin ja cang liwat tukad, tawang yéhé di tukadé belabar sing dadi baan icang nuuk.(PSB, 2010. P 3)

Belog dandanin ja cang liwat tukad,
Belog, hold 5 part me cross river,
Yehe di tukade belabar sing dadi baan icang nuuk,
water in river flood not can by $\mathrm{I}$ gothrough,

Belog, please hold me to cross the river, you konow the river is flooding I cnnot go through

This example illustrates the use of the first person pronoun, cang which is the shorten form of icang. The use of this pronoun indicates that the speaker and addressee are socially of equal status. In the story from which the example is taken, the speaker and addressee are husband and wife and they belong to the jaba caste.

Data $2(\mathrm{kai})$

"Ih iba bojog, kema iba magedi, kai tuara ngelah nasi, kai tuara nyakan". (I Nyoman Jater)

Ih iba bojog, kema iba megedi, kai tuara ngelah nasi, Hi you monkey, there you go, I not have rice,

Kai tuara nyakan

I not cook

'Hi, you are monkey, please go away I do not have rice, I did not cook

This data shows that the speaker uses the first person pronoun, $\boldsymbol{k a i}$, to refer to herself when she is talking to an animal, a monkey which is in the story it was told that the money often comes to her house. The speaker is angry with this situation. In general, the first person pronoun, kai, is used when the speaker is angry to the addressee in the jaba caste. This example shows that the pronoun $k a i$ is also used when talking to a non-human noun.

Data 3 (iraga)

Yen Made Arini tetap sing nyak, iraga masih keweh (TLS, p.66)

Yen Made Arini tetap sing nyak, iraga masih keweh (66)

If Made Arini persistant not want we still difficult.

'If Arini does not agree persistently, we are still in a difficult situation'.

The context of this utterance in the story is that the character who is from a ksatrya caste talking to his wife and son. They are of equal status in terms of caste system. The following example is used by a husband to his wife in the story. They belong to the jaba caste. The same pronoun form is used; this indicates that the pronoun iraga can be used among people of equal status, either from the triwangsa caste or jaba caste.

Sejawaning ento elek pesan rasane I raga teken men Madu (TLS,p.72)

Sejawaning ento elek pesan rasane I raga teken men Madu(72)

in addition that ashamed very feeling we with Mrs Madu.

In addition to that we are ashamed with Mrs.Madu'

Data 5 (titiang) 
The following example shows the use of the first person pronoun titiang. Titiang is a polite form that belongs to the high style of Balinese.

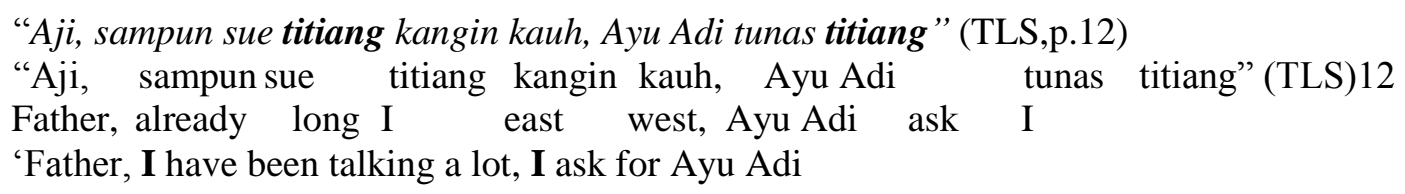

This example is used in situation where the interlocutors are from ksatrya caste. In the story this example is uttered by his son. In this example, the son chose the most polite form of first person pronoun Balinese because he is talking to his father. The following illustrates a different situation in the story; the example below is uttered by a servant from a jaba caste to his superior from a ksatrya caste. The use of titiang indicates that the addressee is a respected individual.

Titiang parek mula jagi nguningayang indik punika ring Iratu (TLS,p.65)

Titiang parek mula jagi nguningayang indik punika ring Iratu (65) Iservant indeed, will tell problem that to you 'I am your servant, I will tell you about that'

\section{Data 6 (tiang)}

The following example uses the first pronoun, tiang. In the story, a young man from a ksatrya caste is talking to an old man from a jaba caste and he is expressing how he feels.

Leek tiang, inget mamisan, nanging anak Len ngajak mabalih filem (TLS,p.74)

Leek tiang, inget mamisan,nanginganak len ngajak mabalihfilem (TLS,p.74) ashamed I remember cousins, but person else ask watch movie

'I am ashamed, I remember we are cousins, but she goes to see a movie with someone else'

The following use of tiang is different. This sentence is said by a son to his mother from a jaba caste. This indicates that the first pronoun tiang can be used by a triwangsa caste and a jaba caste. Alternatively, he can use $\boldsymbol{y}$ ang as a less polite form or he can even use the first person pronoun, $\boldsymbol{c a n g}$. The pronoun tiang is used to show his respect to his mother.

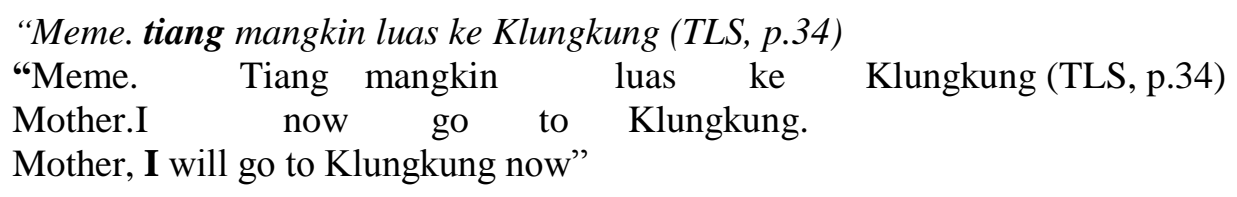

\section{Data 7(yang)}

The following data shows the use of $\boldsymbol{y a n g}$ as a variation form of titiang. The situational context of the use of this utterance in the story is that a respected person from a ksatrya caste visits the house of someone from a jaba caste. He uses the first person pronoun yang to refer to himself when expressing the purpose of his coming. They have known each other well. If not, the first person pronoun that can be used is tiang. It is a safe form to choose when talking to stranger using Balinese. Thus, yang shows respect and familiarity, in this data, it is used by someone from a ksatrya caste to a jaba caste.

Kene yan, keto masih ketut saja yang magumana pesan teka mai (TLS, p.70)

Kene yan, keto masih ketut yang magumanapesan teka mai (TLS, p.70)

This yan, that still ketut I intentionally very come here

'Like this, Yan, and also Ketut I came her with a purpose' 
The use of yang in the following example also indicates that both the speaker and addressee are close friends in the story. They belong to the jaba caste.

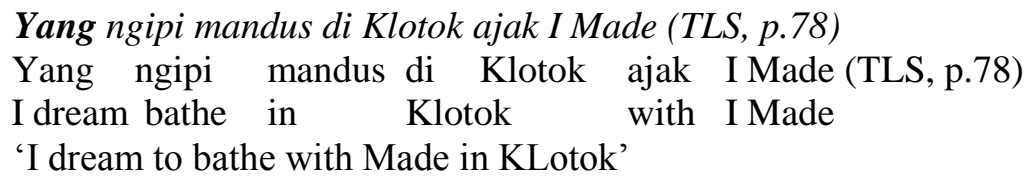

\subsection{The Second Person Pronouns}

The seond person pronouns in Balinese include: cai, nyai, iba I ratu, ragane, and jerone. Each of the use of these second person pronouns is given below.

Data 8 (cai)

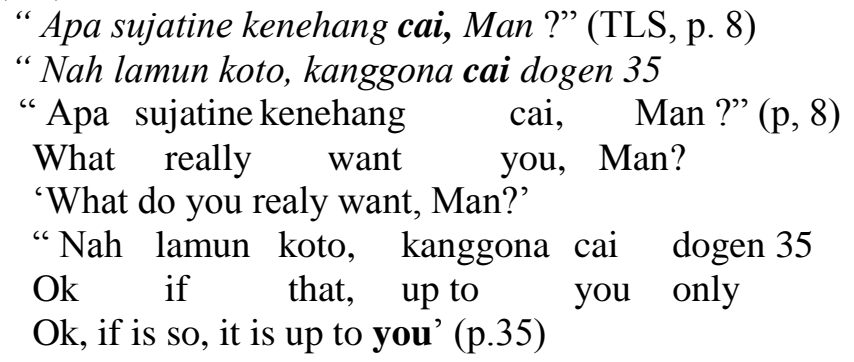

The use of the second person pronoun cai in this data occurs when there is a communication between a mother and her son from a jaba caste. The choice of the pronoun is appropriate. In the story from which this data is taken indicates that the mother is a little angry with her son. The address term commonly used in this context is the form cening. The use of cening shows a friendly and loving conversation between parents and their children in Balinese regardless of their caste affiliation.

Data 9 (nyai)

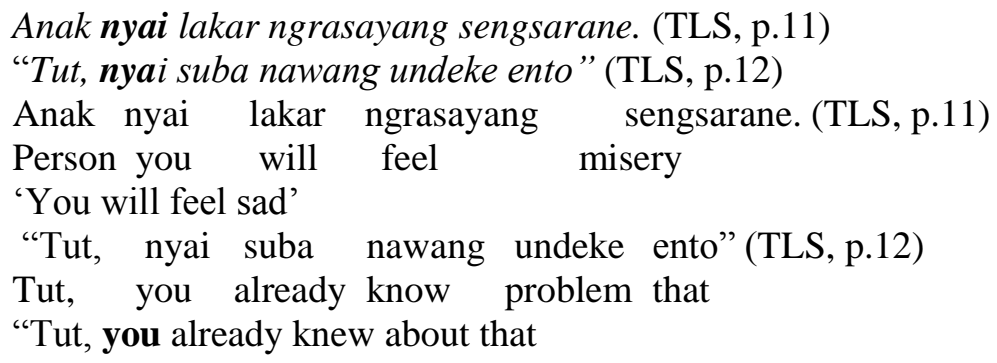

The second person pronoun nyai in this data is used by a husband when speaking to his wife. They are from jaba caste as it is clear from the context of the story from which this data is cited. Balinese only recognizes gender difference in the second person pronoun. Cai is used for male, while nyai is used for female.

Data $10(i b a)$

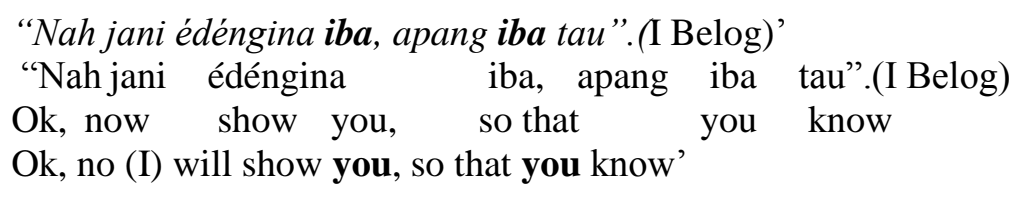

The second person pronoun iba belongs to a low style. It is used in jaba caste. However, the pronoun $i \boldsymbol{b a}$ is used when the speaker is angry. The story from which the data is taken indicates that there is a dialogue between a husband and his wife from jaba caste, but his wife is angry that is the 
reason she used the pronoun $\boldsymbol{i b a}$. Generally this pronoun is avoided, it is offensive. The use of $\boldsymbol{i b a}$ in the following examples occurs when the person from of a kyatria caste is angry with his servant.

Iba, Pan Angklung Gadang, nguda iba belog pesan (Pan Angklung Gadang),

Iba, Pan Angklung Gadang, nguda iba belog pesan (Pan Anglung Gadang),

You, Pan Angklung Gadang, why you stupid very

You, Angklung Gadang, why you are so stupid'

\section{Data 11(ragane)}

"Suba kiap, pesareang dumun ragane" (TLS, p.62)

Yen keten, menengang ragane deriki (TLS. P. 69)

"Suba kiap, pesareang dumun ragane" (TLS, p.62)

Already sleepysleep early yourself

'Are you sleepy, please go to bed'

Yen keten, menengang ragane deriki (TLS. P. 69)

If so, stay yourself here

If so, please you stay here'

The second person pronoun ragane is of a high style. It is used for showing respect or it is also used for person when meeting for the first time. The pronoun ragane in this data is used by someone who meets for the first time. In the story from which the data is taken, the sentence is uttered by the owner of the house when talking to the guest. The ower of the house has been told the guest name is Made Arini. The name indicates that the guest is from from jaba caste.

Data 12 (jerone)

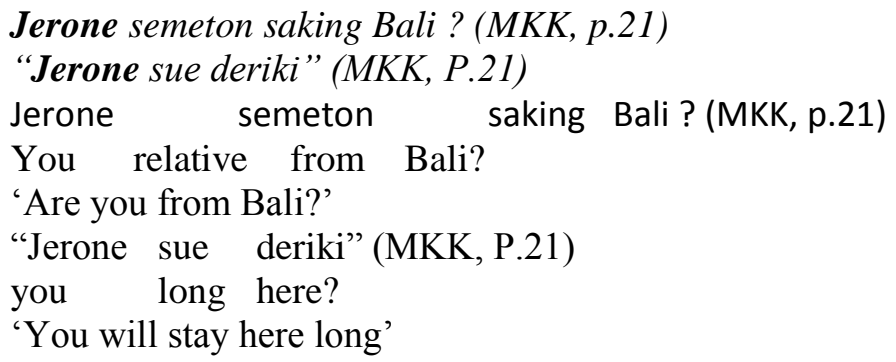

The sentences in data 12 are used by the accommodation staff when talking to a guest who wants to stay in his accommodation. The pronoun jerone is used when someone meets someone else for the first meeting. Thus, jerone is a neutral and polite second person pronoun.

Data 13 (ratu)

Gung Alit, becikan ratu makolem (TLS, p.63)

'Inngih, titiang parek jagi nguningayang indik punika ring iratu (TLS, p.65)'

Gung Alit, becikan ratu makolem (TLS, p.63)

Gung Alit, better you sleep

Gung Alit, it is better for you to sleep'

Titiang parek mula jagi nguningayang indik punika ring Iratu (65)

I servant indeed, will tell problem that to Iratu

Yes, I am your servant, I will tell you about that'

The second pronoun ratu or $\boldsymbol{i}$ ratu in data 13 is used to address someone from a ksatrya caste. In this story the addresser is from a jaba caste. This pronoun is specifically used for addressing someone from a triwangsa caste (a non jaba caste). 


\subsection{The Third Person Pronouns}

The third person pronouns in Balinese are ipun, ida, dane and $i a$. The third pronoun ia is specifically used for a third person pronoun for someone from a jaba caste.

Data 14(ipun)

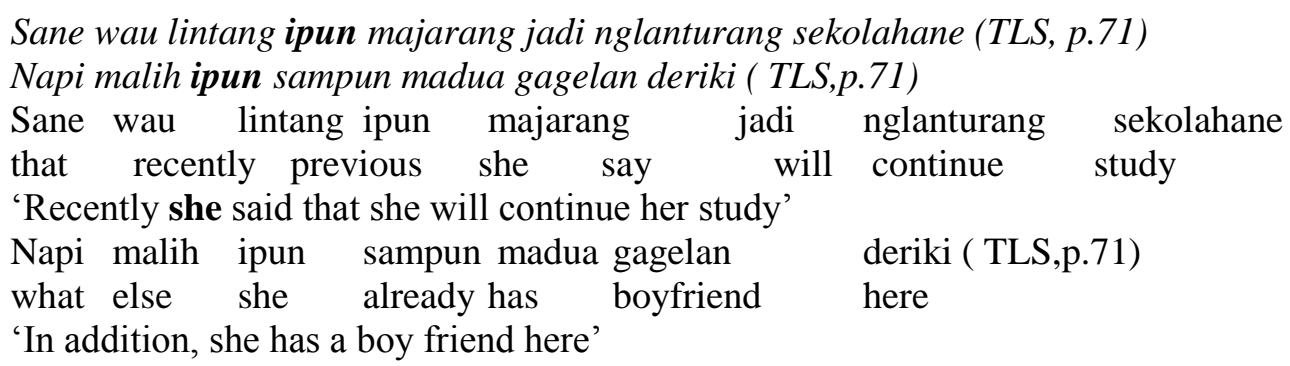

In the story, the pronoun ipun in this data is used to refer to a person from a jaba caste. The context of use is like this: when someone from a ksatrya caste came to the house of a jaba caste. And then they talked about the daughter of the jaba caste. The father of the girl used the pronoun ipun in talking about his daughter to the guest who is from a ksatrya caste. The use of ipun in general can be used to refer to anyone from any castes; the context will determine this.

Data 15 (ida)

Sue ida meneng tan pasaur (TLS, p.68)

Ngaris ida ngambil bukusane di duur mejane laut gagaha (TLS, p.68)

Sue ida meneng tan pasaur (TLS, p.68)

Long he silent not respond

'He is silent for sometime, he does not respond'

Ngaris ida ngambil bukusane di duur mejane laut gagaha( TLS, p.68)

Then he take wrapped rice on table then open

'Then he takes the wrapped rice on the table and then opens it'

The pronoun $\boldsymbol{i d a}$ is used specifically to address somone from a non-jaba caste (brahmana, ksatrya or wiesya caste). In data 15 , the pronoun ida is used to refer to someone from the ksatrya caste. The sentences are used by someone from the jaba caste'

Data 16 (dane)

Dane mula jegeng kasayangang antuk ajine (TLS, p.12)

Sebilang minggu dane ke Selat melali (TLS, p.12)

Dane mula jegeng kasayangang antuk ajine (TLS, p.12)

She indeed beautiful love by her father

'She is truly beautiful and is loved by her father'

Sebilang minggu dane ke Selat melali (TLS, p.12)

Every Sunday she to Selat hangoutaround

'Every Sunday, she goes to Selat for a trip'

The pronoun dane can be used interchangably with the pronoun ida. It is used to refer to someone from a non-jaba caste. These sentences are used by the writer of the story to describe a girl from a non jaba caste.

Data $17(i a)$

Yadiapin ia uli gunung nanging abahne agung tur alep (TLS, p.56)

Suba sesai, meme widin tiang nglemesin, ia tuara nyak (TLS, p.56) 


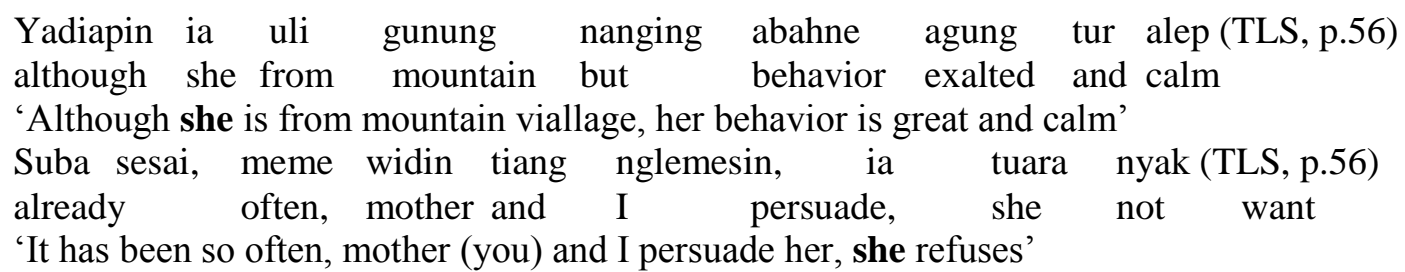

The pronoun $\boldsymbol{i} \boldsymbol{a}$ is only used to refer to someone from a jaba caste. In the story, a family of a ksatrya consisting of the father, mother and son are talking about a girl from the jaba caste that their son loves. They use the pronoun $\boldsymbol{i} \boldsymbol{a}$ to refer to the girl. If the girl is from a non jaba caste they have the options of using the pronoun ida or dane.

Data18 (ida dane)

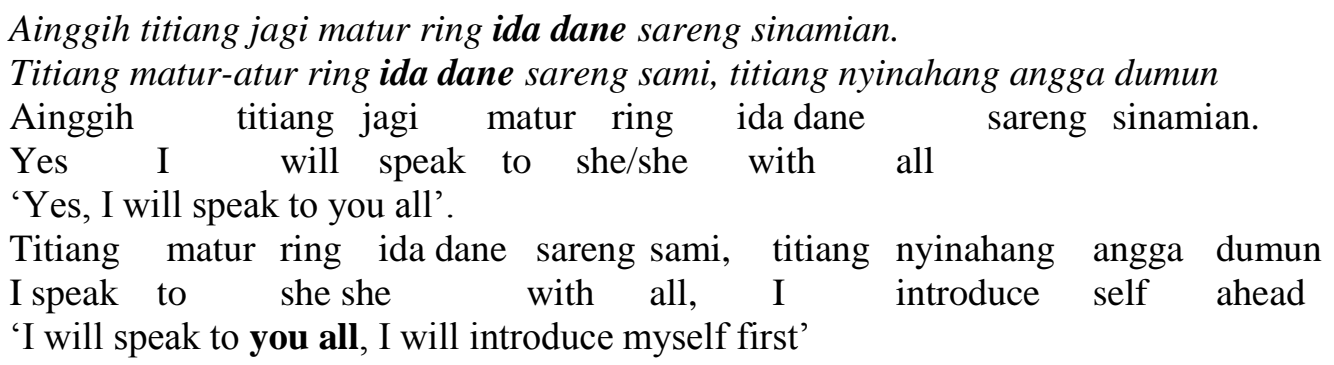

As desribed in data 15 and 16, the forms ida and dane are third peron pronouns. In data 18, the pronouns ida and dane are used as a compound form; they are being put together. The order is fixed, that is ida dane. The reverse is not acceptable. In data 18 this compound form is used to addres the audience as the second person. This is a special use of this compound pronoun. The examples of in data 18 are taken from marriage proposal text. In this marriage negotiation, the people involved can be from any caste. Thus, the uses of these third pronouns are to express politeness through indirect stategy. Another social context for the use of this compound form is in any meeting using Balinese language, for example, the meeting in a village, the chielf of the village at the opening of the meeting will use ida dane form to address the members of the community attending the meeting.

\subsection{Pronoun Elaboration}

In sub-section, the term elaboration is used to describe other words that are used together with the pronoun and the kinship terms which are used like a pronoun.

Data 19 (anak)

Anak nyai lakar ngrasayang sengsarane (TLS, p.11)

Tiang anak sampun nyapih, adenan tiang mati. (TLS, p.69)

Anak cai ngelahang, patapaiana teken bapan caine (TLS, p.9)

Anak nyai akar ngrasayang sengsarane (TLS, p.11)

person You will feel misery

'You will feel the saddness'

Tiang anak sampun nyapih, adenan tiang mati

I person already separated rather I die

'I have nothing to lose, I would rather die'

Anak cai ngelahang, patapaiana teken bapan caine (TLS, p.9)

Person you own be given by father your

'You own it. Your father gave it to you' 
The pronoun elaborator anak, which lexically means 'person' in English, is used in data 19. In this context, the speaker wants to express that the pronoun used is being emphazied. Probably it can be expressed in English using 'the introductory it constrution'. So the translation would be 'it is only you who feel sad'.

Data 20 (ene/ento)

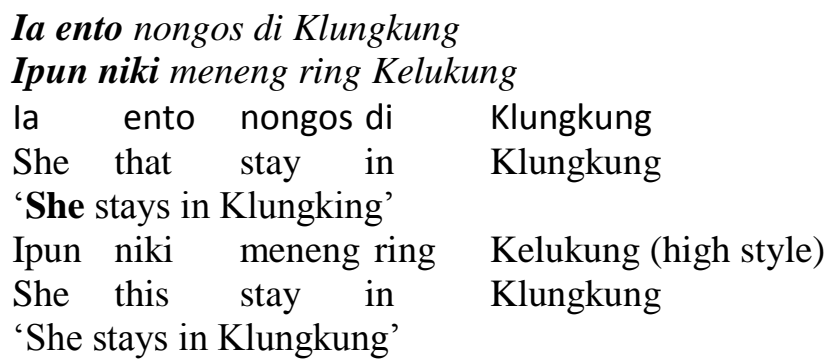

Balinese has demontratives such as this and that in English. These demonstratives have a number of variant forms in accordance with the speech styles. In this example, the low style form is ene 'this' and its high style form is niki 'this'. This pronoun elaboration is used to emphasize the pronoun. In this case, this elaboration has a similar function as anak.

\section{Data 21 (kinship terms)}

The form of kinship terms like beli (elder brother), adi (for younger brother or sister), bapa (father), meme (mother) are used in jaba caste. These forms are deictically used. They can be used for the speaker or addressee.

Buine anake sakit joh joh tekain beli (TLS, p.10)

"Naah, beli merasa teken awak lacur" (TLS, p 10)

Buine anake sakit joh joh tekain beli (TLS, p.10)

again peson sick far far visit elder brother

'More over, some one who is sick far away you visit that person'

"Naah, beli merasa teken awak lacur" (TLS, p 10)

Yes, elder brother realize with self poor

'Yes, I know I am poor'

In Balinese the kinship term beli and adi can be used by a married couple. A husband will use the word beli to refer to himself instead of using a first person pronoun. A wife can also use the word beli to address her husband instead of using the second person pronoun. The examples in data 21 are used by a husband when speaking to his wife. In the story, it is clear they are from jaba caste. Based on this data, the term beli is also used by people from non jaba caste. The following data shows the use of the form beli by someone from a ksatya caste when talking to his older brother. In the following data the form beli can be used to refer to the addressee or to the speaker.

Punika awanan mangkin beli aturin titiang ke Selat (TLS, p.67)

Nah nyen buin ajak beli luas (TLS, p.67)

Punika awanan mangkin beli aturin titiang ke Selat (TLS, p.67)

that reason now elder brother ask I to Selat

'That is why now I will ask you to go to Selat'

Nah nyen buin ajak beli luas (TLS, p.67)

alright, who else with elder brother go?

'Aliright, who else is that I go with'

Data 22 (jegeg) 
The word jegeg in Balinese can be translated into beautiful in English, as in example, Ia jegeg 'she is beautiful'. In every day speech, this word is shortened into geg. It is used as a vocative expression as data below. It is only used for female.

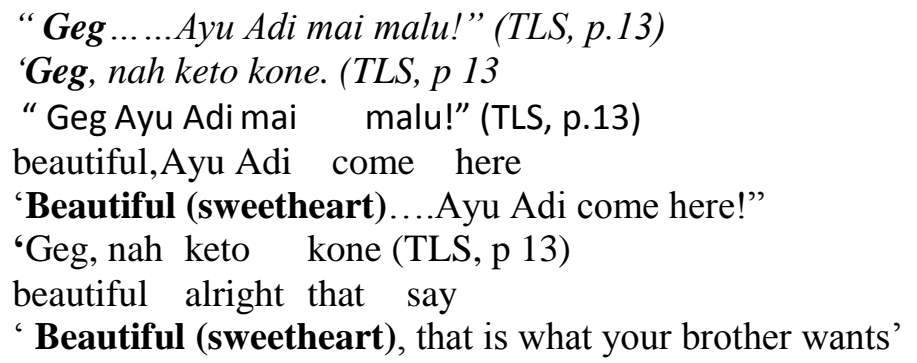

Data 23 (bagus)

The word gus, in this data is the shortend from of the word bagus. The equivalent word of bagus in English is handsome. This from is used for male.

Kene, Gus, adin Ngurahe saja Aji ngelah pianake (TLS, p.12)

Kene, Gus, adin Ngurahe saja Aji ngelah pianake (TLS, p.12)

Look, handsome, sister Ngurahe indeed father have child

'Like this, 'handsome', it is true that she is my daughter'

Data 24 (cening)

The word cening can be used for male and female. The shortened form of this word is ning. The form cening can be used by someone from any caste.

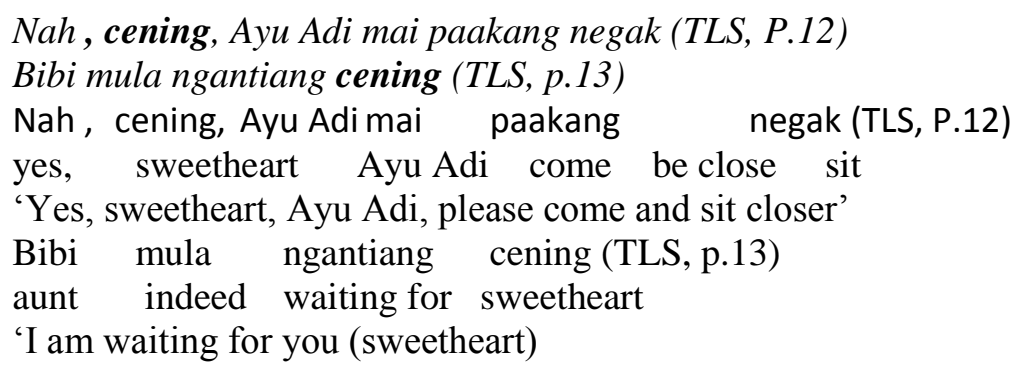

As social creatures, human beings often interact in the culture to communicate messages, share feelings and emotions. Language is a critical point of conversation. It is known to be a tool for conveying meaning; shape cannot be distinguished from meaning in language (Wierzbicka, 1996: 3).

In addition to its function as a means of social interaction, as an ethnic language, Balinese also expresses cultural values that live in the Balinese society as its native speakers. In particular, the language is an integral part of the representation of culture as the personality and cultural identity are created. We share our culture and its ideals through language.

After describing the uses of pronouns based on the written data, it is shown that the caste system is significant in the use of the pronoun and speech styles in Balinese. That is to say that the findings of the present study indicate that the choice of pronoun is determined by the relationship between interlocutors in a speech event. The aspect of intimacy of the interlocutors is not relevant for the choice of the pronouns in Balinese. The aspect of intimacy between interlocutors plays an important role in the choice of the two terms of address in Persian. Two personal pronouns are also found in Persian, namely /to/ and /sïoma/ that are used for a singular addressee. Family acquaintances and peers in casual situations and even lesser age and competence are addressed using the familiar/to/. The deferential/sìoma/ is reserved in formal contexts for superiors or equals (Keshavarz, 2001). 
The uses of the words: bagus /gus 'handsome', jegeng/geg 'beautiful', cening 'young person'and anak 'peron' in Balinese can be regarded as the emergence of a new 'pronoun in Balinese. This phenomenon is found in the English language in the recruitment of the word man as a new pronoun as a grammaticalisation in social context (Cheshire, (2013). In addition to these forms of 'new pronouns', the kinship terms like bapa/aji 'father', meme/biang 'mother', beli 'elder brothor, mbok ' elder sister', and $a d i$ 'younger brother or sister' are used deictically as first person and second person pronouns.

Bentein (2017) pointed out that in "Ancient Greek pronominal reference initially was not used as a 'politeness strategy', in the Post-classical period a T-V distinction did develop. In the Early Byzantine period, I argue, yet another pronominal usage developed: a person could also be addressed in the third person singular". The forms ida and dane are third person pronouns. As described in data 18, the pronouns ida and dane are used as a compound form; they are being put together. The order is fixed, that is ida dane. The reverse is not acceptable. This compound form is used to addres the audience as the second person. The use of these third pronouns is to express politeness through indirect stategy. Another social context for the use of this compound form is in any meeting using Balinese language, for example, the meeting in a village, the chielf of the village at the opening of the meeting will use ida dane form to address the members of the community attending the meeting.

\section{Conclusion}

The choice of pronoun usage in Balinese is determined by the caste system. In terms of communication, the way Balinese greet and speak to the other Balinese is represented through the right choice of lexical items or words. In Balinese culture, the proper use of pronoun is seen as an important element in communicating. This vocabulary types are generally used in accordance with the social standing of conversation participants. Furthermore, the Balinese forms of culture have a strong effect on the politeness of verbal contact in Balinese society. In case of a lack of choice, the addressee can be deemed objectionable and vice versa.

A clear example how social stratification can be established by the vocabulary used can be considered in the balinese language. In this scenario, the pronoun use is the symbol of the adressor and adressor's social standing. In a typical scenario balinese language variations can be found daily between people of higher and lower social status. In oral communication, the paralinguistic aspects or the non verbal aspects in communication such as the distance in speaking, gestures, facial expressions are relevant aspects that show politeness for future research. The focus of the present study is on the pronoun usage based on written data. Personal pronouns are major social categories; they are among the most used terms of conversation, and therefore, they are highly interesting for further studies by looking at spoken data and from different perspectives. For instance it would be interesting to investigate the pronouns used by the intermarriage family of different castes and the pronoun usage by Balinese young generation.

\section{References}

Adelaar, K. A. (2005). Malayo-Sumbawan. Oceanic Linguistics, 44(2), 357-388.

Alwi, H., Dardjowidjojo, S., Lapoliwa, H., \& Moeliono, A. M. (2019). Tata bahasa baku bahasa Indonesia.

Artawa, K., Satyawati, M. S., Asako, S., \& Purnawati, K.W. (2018). Temporal Adverbial Clause Markings In Balinese. International Journal of Linguistics, 10(2), 173-86. 
Artawa, K., Satyawati, M. S., \& Purnawati, K. W. (2020). On the semantic classifications of Balinese adverbial clause. Opción: Revista de Ciencias Humanas y Sociales, (27), 114.

Balhorn, M. (2004). The rise of epicene they. Journal of English Linguistics, 32(2), 79-104. DOI: https://doi.org/10.1177/0075424204265824

Baranowski, M. (2002). Current usage of the epicene pronoun in written English. Journal of Sociolinguistics, 6(3), 378-397. DOI: https://doi.org/10.1111/1467-9481.00193

Bentein, K. (2017). Politeness in Pronouns. Philologus, 161(2), 256267.DOI: https://doi.org/10.1515/phil-2016-5020

Bratayadnya, P. A., Suparwa, N., Yadnya, I. B. P., \& Satyawati, M. S. (2021). The Context of I Lubdaka Maboros. The International Journal of Social Sciences World (TIJOSSW), 3(01), 70-78.

Brown, D and Gilman, A. (1960). The pronouns of power and solidarity. In Style in Language. T. A. Sebeok (ed.), 253-276. Cambridge, MA: MIT Press. Chaika, E. (1982).

Caffi, C., \& Janney, R. W. (1994). Toward a pragmatics of emotive communication. Journal of Pragmatics, 22(3-4), 325-373. https://doi.org/10.1016/0378-2166(94)90115-5

Cheshire, J. (2013). Grammaticalisation in social context: The emergence of a new English pronoun. Journal of Sociolinguistics, 17(5), 608-633.https://doi.org/10.1111/josl.12053

Ekasriadi, I.A. A. and Artawa, I.K, (2019). Directional in the Balinese language.Opción, Regular No.24 (2019), 518-532

Foley, W. A. (1997). Anthropological Linguistics: An Introduction. Oxford: Basil Blackwell.

Gunasari, N. P. C., Budiarsa, M., Artawa, K., \& Satyawati, M. S. (2020). Code-Mixing in Communication between Tour Guides. The International Journal of Language and Cultural (TIJOLAC), 2(01), 87-97.

Heine, B., \& Song, K. A. (2011). On the Grammaticalization of Personal Pronouns. Journal of Linguistics, 47(3), 587-630. https://doi.org/10.1017/S0022226711000016

Holmes, J. (1992). An Introduction to Sociolinguistics. London: Longman.

Keshavarz, M.H. (1988). Forms of address in post-revolutionary Iranian Persian: a sociolinguistic analysis. Language in Society, 17(4), 565-575. DOI: https://doi.org/10.1017/S0047404500013105

Kersten, J., S.V.D. (1984). Bahasa Bali. Ende: Penerbit Nusa Indah.

Kusumarini, I., Simpen, I. W., Budiarsa, M., \& Laksana, I. K. D. (2021). Politeness Strategy of Japanese Hotel Staff in Bali. The International Journal of Language and Cultural (TIJOLAC), $3(01), 9-28$.

Laitinen, M. (2008). Sociolinguistic patterns in grammaticalization: He, they, and those in human indefinite reference. Language Variation and Change, 20(1), 155. DOI: https://doi.org/10.1017/S0954394508000045

Lenard, D.G. (2016). Gender differences in the personal pronouns usage on the corpus of congressional speeches. Journal of research design and Statistics in Linguistics and Communication Science, 3(2), 2016. https://doi.org/10.1558

Lu, X., Sudipa, I. N., Artawa, I. K., \& Suastra, I. M. (2021). The Linguistic Landscape of Dali Ancient City, China. The International Journal of Language and Cultural (TIJOLAC), 3(01), 46-55.

Levinson, S.C. (1983). Pragmatics. Cambridge: Cambridge University Press. 
Martiny, T. (1996). Forms of address in French and Dutch: A sociolinguistic approach. Language Sciences, 18(3-4), 765-775. https://doi.org/10.1016/S0388-0001(96)00046-0

Murphy, G.L. (1988). Personal reference in English. Language in Society, 17(3), 317-349. DOI: https://doi.org/10.1017/S0047404500012938

Purnawati, K.W. and Artawa, K. (2018). Temporal Expressions in Balinese: Focused on The Semantic Functions of Temporal Adverbials. Journal of the Southeast Asian Linguistics Society, 11(2), pp.xxvi-xliv.

Purnawati, K.W. and Artawa, K., (2020). Balinese Adverbial Verbs. International Journal of Psychosocial Rehabilitation, 24(5), 458-485. DOI: 10.37200/IJPR/V24I5/PR201712

Sahoo, K. (2013). Pronouns, Address Forms and Politeness Strategies in Odia. Journal Acta Linguistica Asiatica, 3(1), (2013). DOI: https://doi.org/10.4312/ala.3.1.29-46

Uddin, M. A. (2019). Second Person Pronouns as Person Deixis in Bengali and English: Linguistic Forms and Pragmatic Functions. International Journal of English Linguistics, 10, 4-350. https://doi.org/10.5539/ijel.v10n1p345

Simons, Gary F. and Charles D. Fennig (eds.). (2018). Ethnologue: Languages of the World, Twentyfirst edition. Dallas, Texas: SIL International. Online version: http://www.ethnologue.com.

Sudaryanto. (2015). Metode dan Aneka Teknik Analisis Bahasa: Pengantar

Sulaga, I.N. (1996). Tata Bahasa Baku Bahasa Bali. Denpasar: Pemerintah Provinsi Bali.

Sutjaja, I Gusti Made. (2007). Tiga Satua Bali. Denpasar: Udayana University Press.

Tinggen, I Nengah. (1986). Sor Singgih Basa Bali. Singaraja: Rikha Dewata.

Wierzbicka, Anna. (1996). Semantics Primes and Universals. New York : Oxford University Press.

MiRİCI, I., \& Şeyda, S. A. R. I. (2021). Turkish EFL instructors' feared selves while speaking English in different contexts. Journal of Language and Linguistic Studies, 17(2), 994-1011.

\section{AUTHOR BIODATA}

Made Sri Satyawati is a lecturer at Indonesian Department, Faculty of Humanities, Udayana University, Bali, Indonesia. She obtained her Master Degree in Linguistics from Padjadjaran University, Bandung, Indonesia in 1999 and she got her Doctorate Degree in Linguistics from Udayana University in 2010. Her research interest is in linguistics and she has conducted some researches about syntax, typology, and semantics. Her publications involve study on Indonesian language and some local languages in Eastern Indonesia. She has supervised many bachelor papers, theses and doctorate dissertations. She has also participated as guest and invited speaker in a number of national and international seminars.

Ketut Artawa is a Professor of linguistics at the Faculty of Humanities Udayana University, Bali Indonesia. He obtained his MA in Linguistics in 1992 and PhD in Linguistics in 1995 from La Trobe University, Melbourne. He was a visiting Professor at the Research School of Pacific Studies, the Australian National University (October 2009-January 2010) and a Visiting Professor at the Research Institute for Languages and Cultures of Asia and Africa (ILCAA/ AA-ken), Tokyo University of Foreign Studies (TUFS), Japan (2011-2012). His research interests are in the fields of syntax, semantics, language typology, and linguistic landscape. He has published a number of articles in International journals with his research group including in Studies in language 1977, 21(3) pp 483-508 and Cognitive science 2021, 45(4), e1294. He has supervised 25 PhD graduates in Linguistics and he has participated in a number of international conferences on linguistics.

I Nyoman Kardana is a professor in Linguistics at Faculty of Letters Warmadewa University, Bali Indonesia. 
He received his Master Degree in Linguistics from Padjadjaran University, Bandung, Indonesia in 1998. He obtained his Doctorate Degree in Linguistics from Udayana University, Bali, Indonesian 2004. He has been doing some researches related to the topics about morpho-syntax, semantics, and eco-linguistics. He has supervised many papers, theses and doctorate dissertations. He has also written a lot of articles published in national and international journals. He has participated in a number of national and international seminars as well. 